\title{
Syntheses and absorption-structure relationships of some new photosensitizer cyanine dyes
}

\author{
H A SHINDY and A I M KORAIEM \\ Chemistry Department, Aswan Faculty of Science, Aswan, Egypt
}

MS received 25 May 2000; revised 6 June 2001

\begin{abstract}
New biheterocyclic compound was synthesized as starting material to prepare new photosensitizers mono-, tri-, substituted tri-, azadimethine and mixed cyanine dyes. Absorption-structure relationship of the synthesized cyanine dyes were determined by studying their electronic spectral behaviour in ethanol. The structure of the compounds were identified by elemental analysis, IR and ${ }^{1} \mathrm{HNMR}$ spectral data.
\end{abstract}

Keywords. Cyanine dyes; absorption-structure relationship; photosensitizer dyes; biheterocyclic compounds.

\section{Introduction}

Cyanine dyes find extensive application as photosensitizers in blue green light ${ }^{1}$. Some of these dyes are growth inhibitors to bacteria ${ }^{2}$ and to the mitosis of fertilized sea urchin eggs $^{3}$. They possess hormonal effects on plant growth ${ }^{4}$ and can be used for the determination of the sensitivity of micro-organism to antibiotics ${ }^{5}$. They can also be used as laser dyes ${ }^{6,7}$ and producing offset printing plates ${ }^{8,9}$.

\section{Results and discussion}

\subsection{Synthesis}

As an extension to our previous publications ${ }^{10,11}$, 4-bromo-3-methyl-1-phenyl-pyrazole5-one (1) was reacted with diphenyl urea in equimolar ratios and in ethanol/pyridine to achieve 3-methyl-1,4-diphenyl-1H-pyrazolo[4,5- $d][1,3]$ oxazole-5-phenyl azomethine (2). Hydrolysis of 2 in $\mathrm{H}_{2} \mathrm{SO}_{4} / \mathrm{EtOH}$ furnished 3-methyl-1,4-diphenyl-1H-pyrazolo[4,5d][1,3] oxazole-5-one (3). Quaternization of (3) using iodoethane resulted in its 2-ethyl iodide salt (4) (scheme 1, table 1).

Interaction of equimolar ratios of (3) and 2(4)-methyl quaternary salts such as 1-ethyl2-methyl-pyridinium iodide, 1-ethyl-2-methyl-quinolinium iodide and 1-ethyl-4-methylpyridinium iodide in ethanol as organic solvent and piperidine as basic catalyst produced the 5[2(4)]-monomethine cyanine dyes (5a-c) (scheme 1, table 2). Otherwise, interaction of the quaternized compound (4) with equimolar amounts of iodoethane quaternary salts of pyridine, quinoline and isoquinoline in ethanol under piperidine catalysis afforded the 3[4(1)]-monomethine cyanine dyes (6a-c) (scheme 1, table 2).

On the other hand, interaction of the quaternized compound (4) with equimolar amounts of triethyl orthoformate in ethanol under piperidine catalysis furnished the intermediate compound (7). Further reaction of $\mathbf{7}$ with the N-iodoethane quaternary salt 


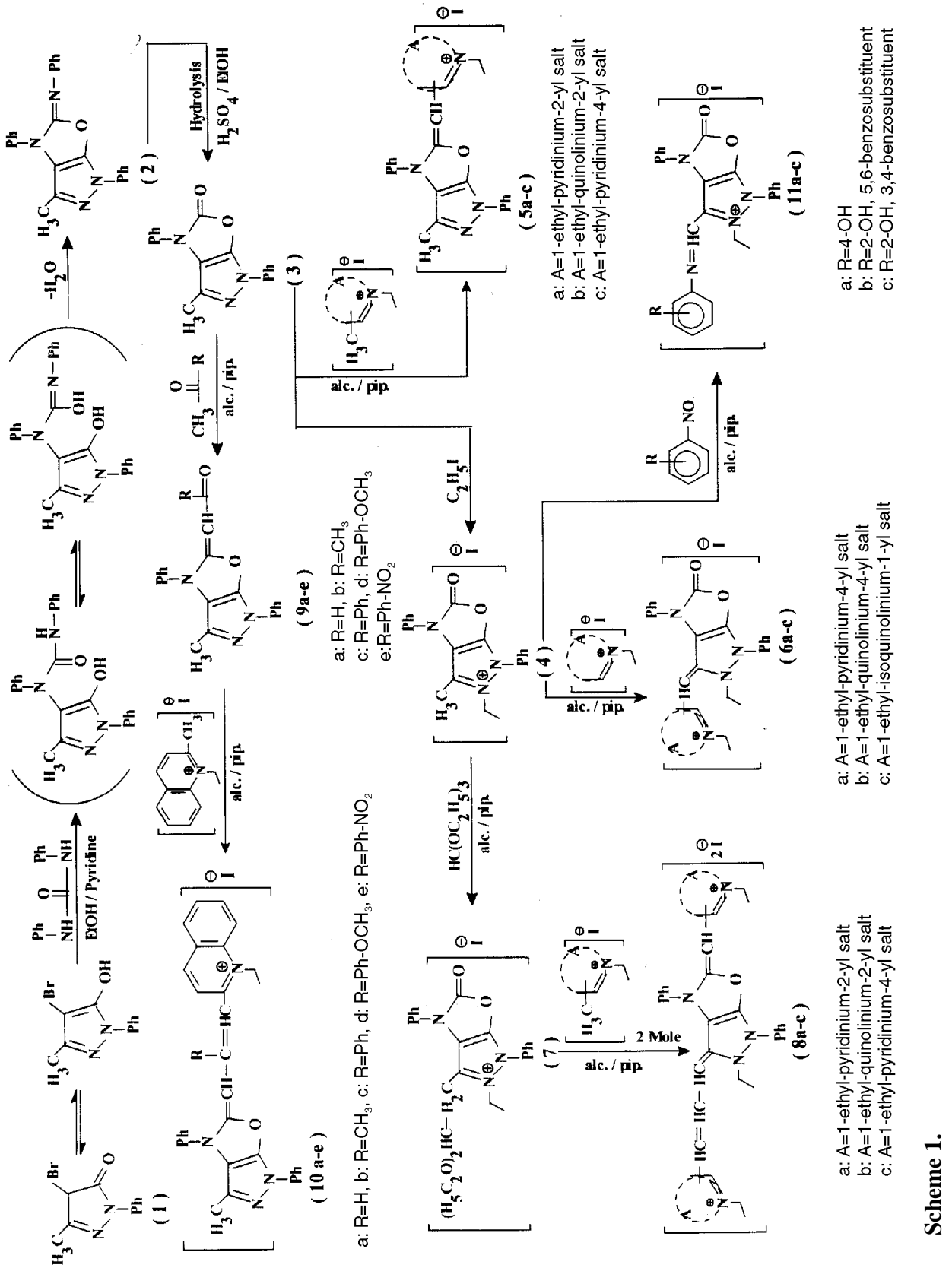


Table 1. Characterization of 3-methyl-1,4-diphenyl-1H-pyrazolo[4,5-d][1,3] oxazole-5-phenyl azomethine (2), 3-methyl-1,4-diphenyl-1H-pyrazolo [4,5- $d][1,3]$ oxazole-5-one (3) and its 2-ethyl iodide salt (4).

\begin{tabular}{|c|c|c|c|c|c|c|c|}
\hline \multirow{3}{*}{$\begin{array}{l}\text { Compd. } \\
\text { no. }\end{array}$} & \multirow{3}{*}{$\begin{array}{l}\text { m.p. } \\
\left({ }^{\circ} \mathrm{C}\right)\end{array}$} & \multirow{3}{*}{$\begin{array}{l}\text { Yield } \\
(\%)\end{array}$} & \multirow{3}{*}{$\begin{array}{l}\text { Mol. formula } \\
\text { (mol. wt.) }\end{array}$} & \multirow{3}{*}{$\begin{array}{l}\text { Colour of } \\
\text { crystals }\end{array}$} & \multicolumn{3}{|c|}{ Analysis (\%) } \\
\hline & & & & & \multicolumn{3}{|c|}{ Calcd. (Found) } \\
\hline & & & & & $\mathrm{C}$ & $\mathrm{H}$ & $\mathrm{N}$ \\
\hline 2 & 185 & 43 & $\begin{array}{c}\mathrm{C}_{23} \mathrm{H}_{18} \mathrm{~N}_{4} \mathrm{O} \\
(366)\end{array}$ & Red/brown & $\begin{array}{c}75.40 \\
(75.42)\end{array}$ & $\begin{array}{c}4.91 \\
(4.95)\end{array}$ & $\begin{array}{c}15.30 \\
(15.33)\end{array}$ \\
\hline 3 & 130 & 84 & $\begin{array}{c}\mathrm{C}_{17} \mathrm{H}_{13} \mathrm{~N}_{3} \mathrm{O}_{2} \\
(291)\end{array}$ & Pale brown & $\begin{array}{c}70.10 \\
(70.15)\end{array}$ & $\begin{array}{c}4.46 \\
(4.49)\end{array}$ & $\begin{array}{r}14.43 \\
(14.45)\end{array}$ \\
\hline 4 & 150 & 98 & $\begin{array}{c}\mathrm{C}_{19} \mathrm{H}_{18} \mathrm{~N}_{3} \mathrm{O}_{2} \mathrm{I} \\
(447)\end{array}$ & Brown & $\begin{array}{c}51.00 \\
(51.04)\end{array}$ & $\begin{array}{c}4.02 \\
(4.05)\end{array}$ & $\begin{array}{r}9.39 \\
(9.43)\end{array}$ \\
\hline
\end{tabular}

of $\alpha$ picoline, quinaldine and $\gamma$ picoline in 1:2 molar ratios in ethanol and in presence of piperidine as catalyst gave the 3[2(4)]-tri-5[2(4)]-mono-methine mixed cyanine dyes (8a-c) (scheme 1, table 3).

Additionally, interaction of equimolar ratios of (2) and methyl carbonyl compounds such as acetaldehyde, acetone, acetophenone, $p$-methoxy acetophenone and $p$-nitro acetophenone in ethanol under piperidine catalysis resulted in 5-acylmethylideno derivatives (9a-e) as intermediate compounds. Further reaction of (9a-e) with 1-ethyl-2-methylquinolinium iodide in equimolar ratios, in ethanol as solvent and piperidine as catalyst furnished 5(2)-tri-(substituted tri-) methine cyanine dyes (10a-e) (scheme 1, table 4).

3(1)-Azadimethine cyanine dyes $(\mathbf{1 1 a}-\mathbf{c})$ were also prepared via interaction of equimolar ratios of the quaternized compound (4) and nitroso compounds such as $p$ nitroso phenol, $\boldsymbol{\alpha}$ nitroso- $\beta$-naphthol and $\boldsymbol{\beta}$-nitroso- $\boldsymbol{\alpha}$ naphthol in ethanol and presence of piperidine (scheme 1 , table 5).

The structures of the synthesized compounds were characterized by elemental analysis, $\mathrm{IR}^{12}$ and ${ }^{1} \mathrm{H} \mathrm{NMR}^{13}$ spectral data.

\subsection{Characterization}

The synthesized cyanine dyes are highly coloured compounds, partially soluble in nonpolar organic solvents and easily soluble in polar organic solvents giving coloured solutions, accompanied by pale to intense fluorescence. The intensity and colour of the fluorescence depends upon the type of dye and solvent used. The dyes are soluble in concentrated $\mathrm{H}_{2} \mathrm{SO}_{4}$, liberating iodine vapour on warming. They are also $p \mathrm{H}$-sensitive dyes, and hence their ethanolic solutions give changeable colours in acid/base media being yellow or colourless on acidification and getting back their intense colour on basification. The intensity of their colour is due to the two suggested mesomeric structures (A and B) having delocalized positive charges over the conjugated system (scheme 2).

\subsection{Absorption-structure relationship}

Absorption-structure relationships of the prepared cyanine dyes were determined by studying their electronic absorption spectral behaviour in $95 \%$ ethanol. Thus, the 


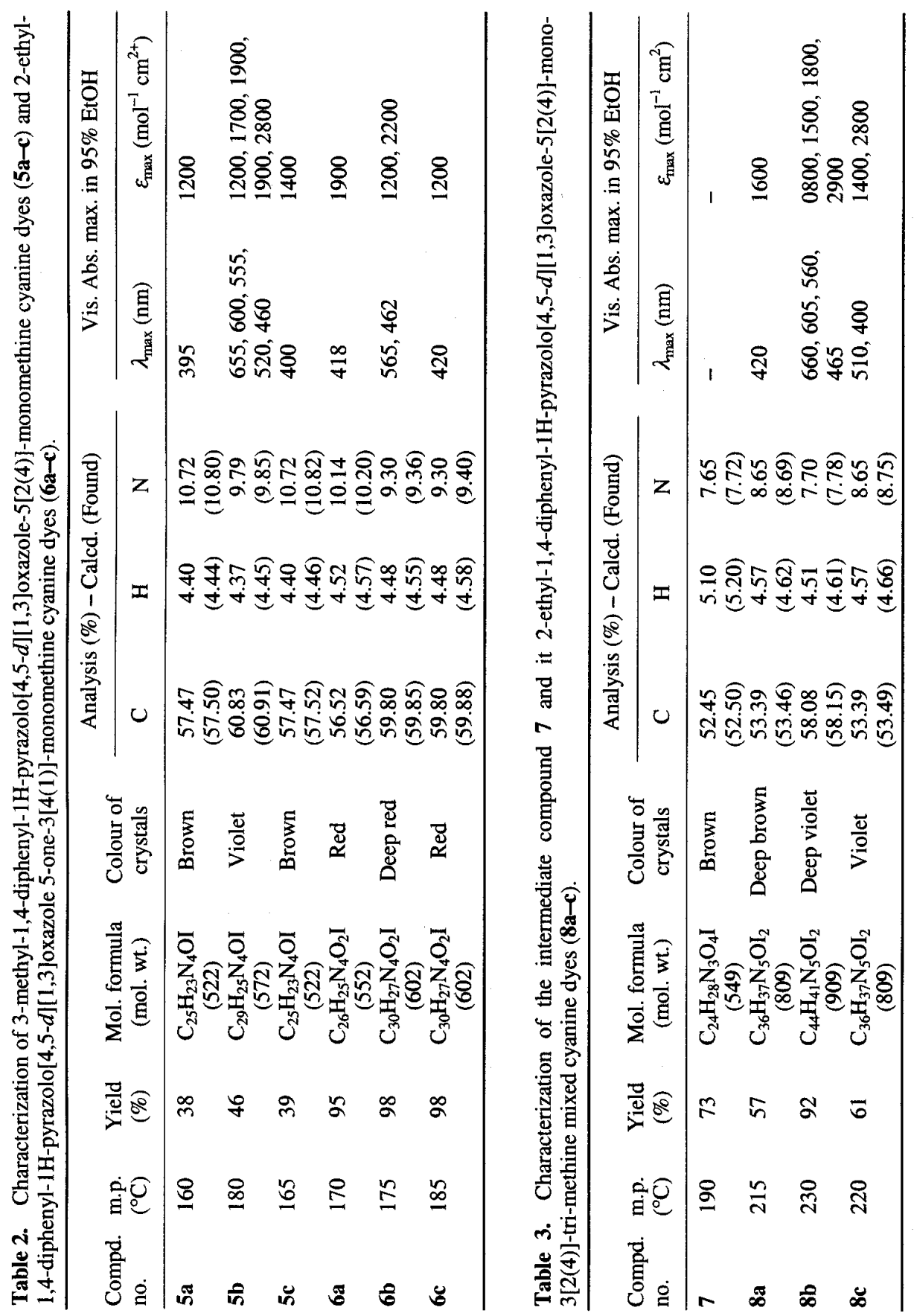




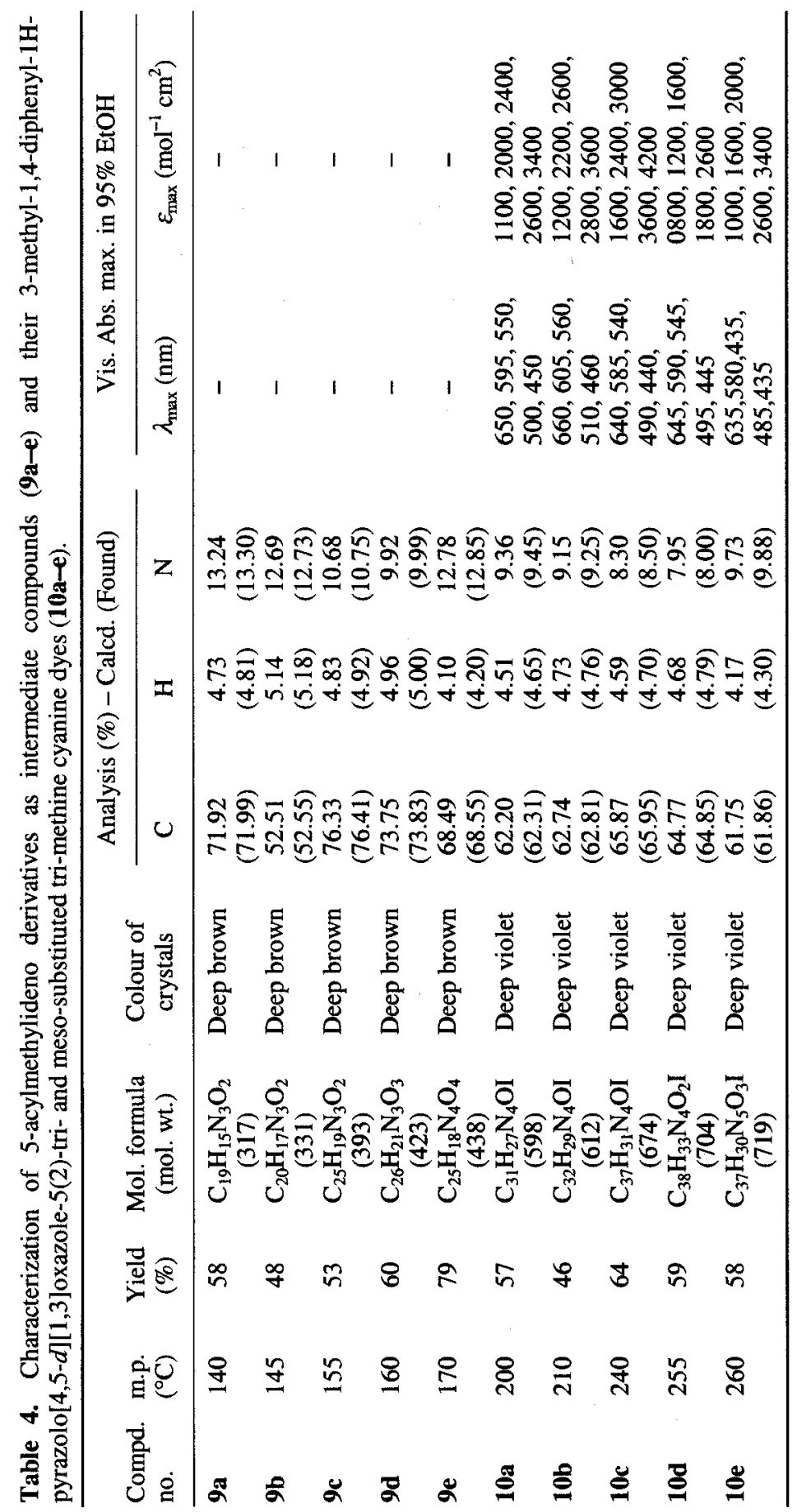




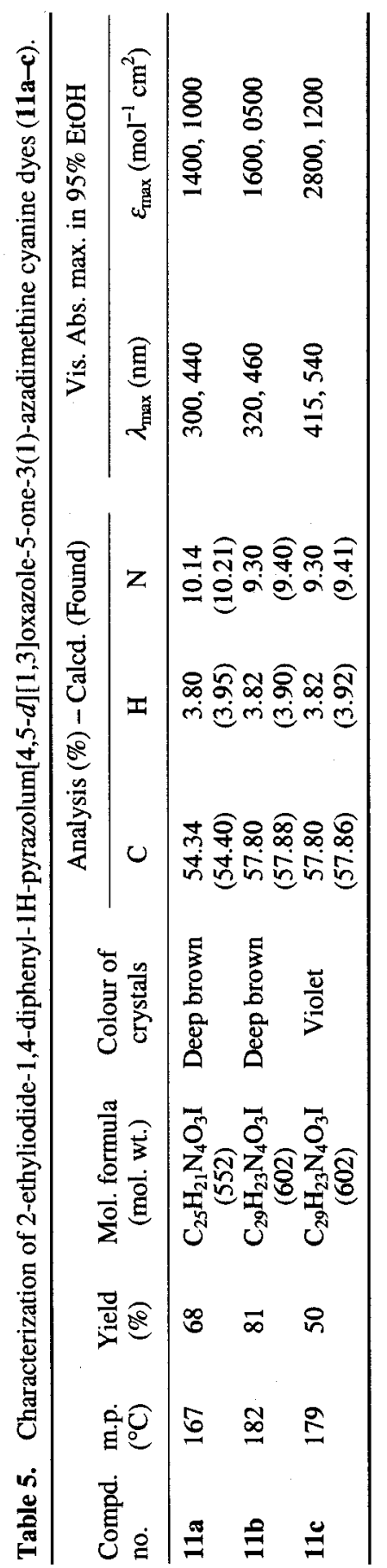



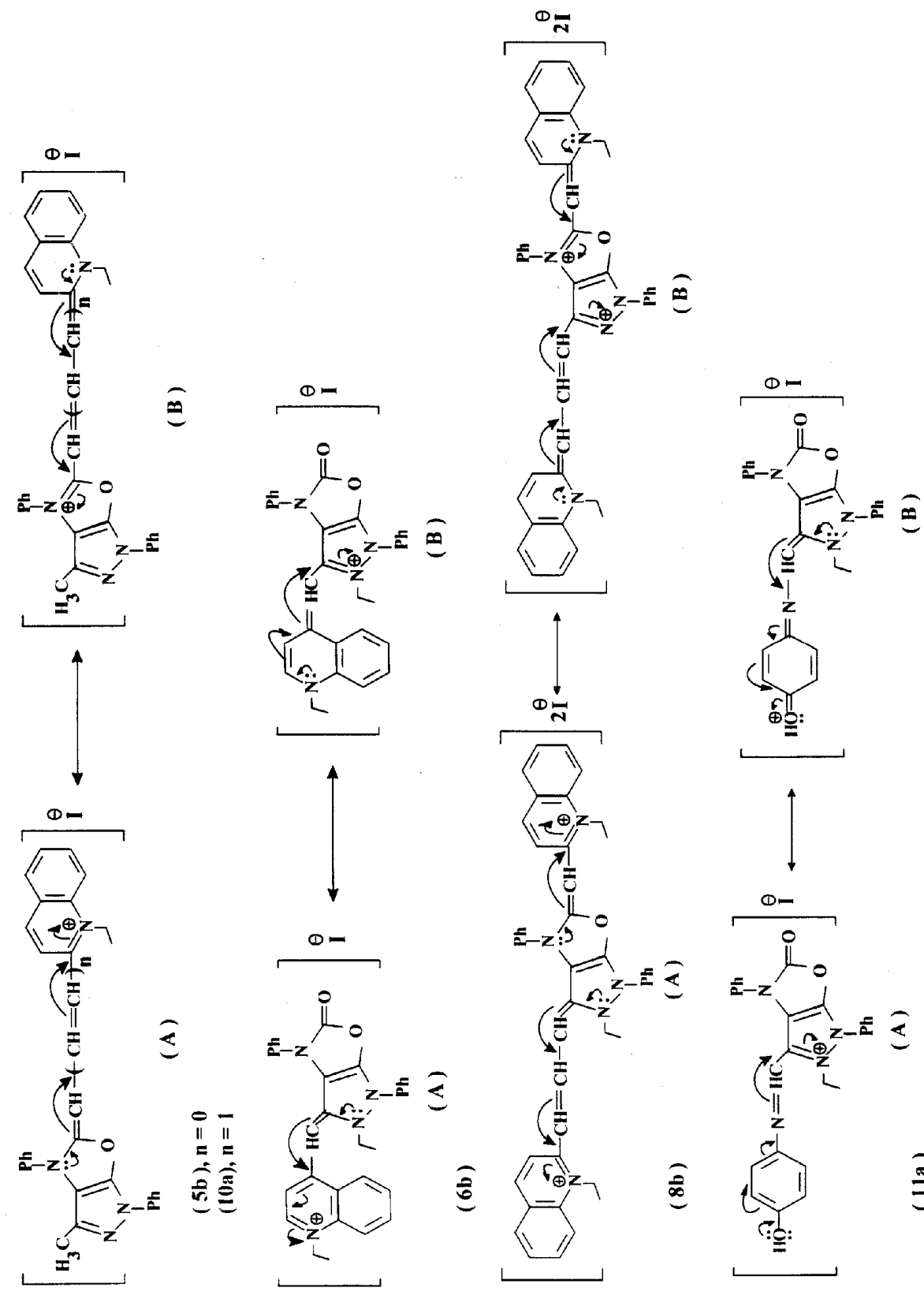

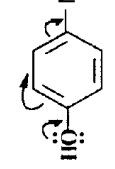

$\approx$
$=$
¿ 
electronic absorption spectra of the monomethine cyanines 5a-c (6a-c) showed absorption bands that underwent bathochronic or hypsochromic shifts depending upon the nature of the heterocyclic quaternary moieties and their linkage position. Therefore, the absorption spectra of the monomethine cyanine dyes $\mathbf{5 a}(\mathbf{6 a}), \mathrm{A}=1$-ethyl-pyridinium2-yl salt (1-ethyl-pyridinium-4-yl salt) showed absorption bands hypsochromically shifted if compared with the dyes $\mathbf{5 b}(\mathbf{6 b}), \mathrm{A}=1$-ethyl-quinolinium-2-yl salt (1-ethylquinolinium-4-yl salt), with increasing number and intensity of the absorption bands for the latter dyes (table 2, scheme 1). This is due to the extra conjugation in quinoline. Additionally, changing the linkage position of the pyridinium (quinolinium) residue from the 2-yl salt (4-yl salt) in dyes 5a (6b) to the 4-yl salt (1-yl salt) in dyes $\mathbf{5 c}(\mathbf{6 c}), \mathrm{A}=1$ ethyl-pyridinium-4-yl salt (1-ethyl isoquinolinium 1-yl salt), resulted in bathochromic (hypsochromic) shifts of absorption bands with increasing (decreasing) intensity of the absorption bands (table 2, scheme 1). This is due to increasing (decreasing) conjugation in the substituted heterocyclic quaternary residue in $\mathbf{5 c}(\mathbf{6 c})$ than its analogous $5 \mathbf{a}(\mathbf{6 b})$ (table 2, scheme 1).

Also the electronic absorption spectra of the 5[2(4)]-mono-3[2(4)]-tri-methine mixed cyanine dyes $(\mathbf{8 a}-\mathbf{c})$ showed absorption spectra bands, their positions and intensity depending upon the nature of the heterocyclic quaternary residue A. Thus, substituting $\mathrm{A}=1$-ethylpyridinium-2-yl salt in the 5(2)-mono-3(2)-tri-methine mixed cyanine dye (8a) by $\mathrm{A}=1$-ethyl-quinolinium-2-yl-salt to give the 5(2)-mono-3(2)-tri-methine mixed cyanine dye $(\mathbf{8 b})$ causes a bathochromic shift accompanied by increasing number and intensity of the absorption bands (table 3, scheme 1). This is due to increasing conjugation in the quinolinium salt residue compared that in the pyridinium salt residue. Otherwise, substituting $A=1$-ethyl-pyridinium-2-yl salt by $A=1$-ethyl-pyridinium-4-yl salt transferring from 5(2)-mono-3(2)-tri-methine mixed dye (8a) to 5(4)-mono-3(4)-trimethine mixed dye $(\mathbf{8 c})$ resulted in a bathochromic shift and increasing number of absorption bands (table 3 , scheme 1). This is due to increasing conjugation in pyridinium4-yl salt compared to its analogous pyridinium-2-yl salt.

On the other hand, the position and molar extinction coefficients of the absorption bands in the electronic absorption spectra of 5(2)-tri- and meso-substituted tri-methine cyanine dyes (10a-e) were influenced by the meso-substituted $\mathrm{R}$ in the diene side chain. Thus, substituted $\mathrm{R}=\mathrm{H}$ in dye (10a) by $\mathrm{R}=\mathrm{CH}_{3}$ to give dye (10b) causes a bathochromic shift owing to the donating nature of the $\mathrm{CH}_{3}$ group. Reversibly substituting $\mathrm{R}=\mathrm{H}$ by $\mathrm{R}=\mathrm{C}_{6} \mathrm{H}_{5}$ passing from dye (10a) to dye (10c) causes a hyposchromic shifts for the absorption bands (table 4, scheme 1). This is due to the electron-attracting character of the benzene ring. It is also interesting to note that the position of the absorption spectra bands of the dye (10c), $\mathrm{R}=\mathrm{C}_{6} \mathrm{H}_{5}$ is hypsochromically shifted if compared with the dye (10d), $\mathrm{R}=\mathrm{C}_{6} \mathrm{H}_{5}-\mathrm{OCH}_{3}$ and bathochromically shifted if compared with the dye (10e), $\mathrm{R}=\mathrm{C}_{6} \mathrm{H}_{5}-\mathrm{NO}_{2}$ (table 4, scheme 1). This is due to the electron-donating nature of the $\mathrm{OCH}_{3}$ group and the electron-attracting nature of the $\mathrm{NO}_{2}$ group in the dyes (10d) and (10e) respectively.

3(1)-Azadimethine cyanine dyes (11a-c) showed electronic absorption spectra bands, their positions underwent bathochromic or hypsochromic shifts depending upon the type of substituent $\mathrm{R}$ in the benzene ring attached to the azomethine $(-\mathrm{N}=\mathrm{CH})$ group. Thus, the dyes $11 \mathrm{~b}$ (11c), $\mathrm{R}=2-\mathrm{OH}, 5,6-$ benzosubstituent (2-OH-3,4-benzosubstituent) showed absorption bands bathochromically shifted if compared with the dye (11a), $\mathrm{R}=4-\mathrm{OH}$ (table 5, scheme 1). This is due to the increasing conjugation in the naphthyl rings in dyes (11b), (11c) compared with the phenyl ring in dye (11a). Also the dye 11c, $\mathrm{R}=2-\mathrm{OH}-$ 
3,4-benzosubstituent showed absorption spectra bands bathochromically shifted with intensification if compared with the dye (11b), $\mathrm{R}=2-\mathrm{OH}-5,6$-benzosubstituent (table 5, scheme 1). This may be attributed to the higher planarity of the dye (11c).

\section{Experimental}

\subsection{General}

All melting points are uncorrected. Elemental analysis were carried out at the Microanalytical Center of Cairo University. IR spectra were determined on a Perkin-Elmer Infrared 127 spectrophotometer (Cairo University), and the ${ }^{1} \mathrm{H} N \mathrm{MR}$ spectra were obtained using an Em-390 spectrophotometer (Cairo University). Electronic Visiple Absorption spectra were carried out on a Shimadzu UV-VIS 240 spectrophotometer (Faculty of Science, Aswan).

\subsection{Synthesis}

Synthesis of individual dyes are detailed below.

3.2a 3-Methyl-1,4-diphenyl-1H-pyrazolo[4,5-d][1,3]oxazole-5-phenyl azomethine (2): Equimolar ratios of 4-bromo-5-pyrazolone 1 (2.53 gm, 0.01 mole) and diphenyl urea $(2.12 \mathrm{gm}, 0.01 \mathrm{~mole})$ were dissolved in a mixture of ethanol $(50 \mathrm{ml})$ and pyridine $(20 \mathrm{ml})$. The reaction mixture was refluxed for $8-10 \mathrm{~h}$, filtered while hot, and acidified with concentrated hydrochloric acid. The product which precipitated out on addition of icecold water was filtered off, washed several times with water, dried and recrystallized from ethanol to give (2) as red/brown crystals. Relevant data are given in table 1.

IR spectrum $(\mathrm{KBr})\left(\mathrm{cm}^{-1}\right)$ for 2: 696, 754 (benzene mono-substituted); 1052, 1155 (CO-C cyclic); $1312(\mathrm{C}-\mathrm{N}) ; 1596(\mathrm{C}=\mathrm{N}), 1649(\mathrm{C}=\mathrm{C})$.

${ }^{1} \mathrm{H}$ NMR spectrum $\left(\mathrm{CDCl}_{3}\right)$ (8) for 2: $0.85\left(s, 3 \mathrm{H}, \mathrm{CH}_{3} \mathrm{H}\right.$-atoms); 6.6-8.8 (m, 15H, aromatic $\mathrm{H}$-atoms).

3.2b Synthesis of 3-methyl-1,4-diphenyl-1H-pyrazolo[4,5-d][1,3]oxazole-5-one (3): $40 \%$ sulphuric acid $(50 \mathrm{ml})$ was added to a suspension of $2(1 \mathrm{gm}, 0.003 \mathrm{~mole})$ in ethanol $(50 \mathrm{ml})$. The mixture was refluxed for $2 \mathrm{~h}$, until 2 dissolved, and then heated for an additional $1 \mathrm{~h}$, cooled and diluted with an equal volume of water whereupon the unchanged 2 that precipitated was filtered off, and the filtrate extracted with chloroform. The extract was concentrated to near dryness, yielding pale brown product, which was recrystallized from excess ethanol to give pale brown crystals of $\mathbf{3}$. The results are listed in table 1.

IR spectrum $(\mathrm{KBr})\left(\mathrm{cm}^{-1}\right)$ for 3: 694, 752 (benzene mono-substituted); 1073, 1176 (C-O-C cyclic); $1312(\mathrm{C}-\mathrm{N}) ; 1597(\mathrm{C}=\mathrm{N}), 1651(\mathrm{C}=\mathrm{C}) ; 1700(\mathrm{C}=\mathrm{O})$.

${ }^{1} \mathrm{H}$ NMR spectrum $\left(\mathrm{CDCl}_{3}\right)$ (d) for 3: $0.9\left(s, 3 \mathrm{H}, \mathrm{CH}_{3} \mathrm{H}\right.$-atoms); 6.7-8.0 (m, $10 \mathrm{H}$, aromatic $\mathrm{H}$-atoms).

3.2c 2-Ethyliodide-3-methyl-1,4-diphenyl-1H-pyrazolum[4,5-d][1,3]-oxazole-5-one

(4): A pure sample of 3 (2.91 gm, 0.01 mole) was suspended in excess iodoethane and heated in a sealed tube in an electric oven at $140^{\circ} \mathrm{C}$ for $3 \mathrm{~h}^{14,15}$. The sealed tube was first cooled, 
then opened and the product (4) collected, washed with ether and recrystallized from ethanol to give brown crystals. The results are summarized in table 1 .

IR spectrum $(\mathrm{KBr})\left(\mathrm{cm}^{-1}\right)$ for 4: 693, 753 (benzene mono-substituted); 1072, $1175(\mathrm{C}-$ $\mathrm{O}-\mathrm{C}$ cyclic); $1310(\mathrm{C}-\mathrm{N}) ; 1547(\mathrm{C}=\mathrm{N}), 1597(\mathrm{C}=\mathrm{C}) ; 1703(\mathrm{C}=\mathrm{O}) ; 2922$ (quaternary salt).

${ }^{1} \mathrm{H}$ NMR spectrum $\left(\mathrm{CDCl}_{3}\right)(\delta)$ for $(4): 1.0\left(s, 3 \mathrm{H}, \mathrm{CH}_{3} \mathrm{H}\right.$-atoms at position 3$) ; 1.35(t$, $3 \mathrm{H}, \mathrm{CH}_{3} \mathrm{H}$-atoms of $\mathrm{CH}_{3} \mathrm{CH}_{2} \mathrm{~N}^{+}$-pyrazolum); $2.25\left(q, 2 \mathrm{H}, \mathrm{CH}_{2} \mathrm{H}\right.$-atoms of $\mathrm{CH}_{3} \mathrm{CH}_{2} \mathrm{~N}^{+}-$ pyrazolum); 6.7-8.5 ( $m, 10 \mathrm{H}$, aromatic $\mathrm{H}$-atoms).

3.2d 3-Methyl-1,4-diphenyl-1H-pyrazolo[4,5-d][1,3]oxazole-5[2(4)]-monomethine cyanine dyes $(\mathbf{5 a}-\boldsymbol{c})$ : Piperidine (5-7 drops) was added to a mixture of equimolar ratios ( $2.91 \mathrm{gm}, 0.01 \mathrm{~mole})$ of $\mathbf{3}$ and the iodoethane quaternary salt of $\alpha$ picoline ( $2.49 \mathrm{gm}$, 0.01 mole), quinaldine $(2.99 \mathrm{gm}, 0.01 \mathrm{~mole}), \gamma$ picoline $(2.49 \mathrm{gm}, 0.01 \mathrm{~mole})$ in ethanol $(50 \mathrm{ml})$. The reaction mixture was refluxed for $3-5 \mathrm{~h}$, filtered while hot, concentrated, cooled, acidified with acetic acid and precipitated by addition of cold water. The precipitate was filtered, washed with water, and recrystallized from ethanol. The results are given in table 2 .

IR spectrum $(\mathrm{KBr})\left(\mathrm{cm}^{-1}\right)$ for $5 \mathbf{5 b}$ : 694, 753 (benzene mono-substituted); 833, 896 (benzene disubstituted); 1048, $1187(\mathrm{C}-\mathrm{O}-\mathrm{C}$ cyclic); $1310(\mathrm{C}-\mathrm{N}) ; 1543(\mathrm{C}=\mathrm{N}), 1597$ $(\mathrm{C}=\mathrm{C}) ; 2925$ (quaternary salt).

${ }^{1} \mathrm{H}$ NMR spectrum $\left(\mathrm{CDCl}_{3}\right)(\delta)$ for $\mathbf{5 b}: 0.95\left(s, 3 \mathrm{H}, \mathrm{CH}_{3} \mathrm{H}\right.$-atoms at position 3$) ; 1.5(t$, $3 \mathrm{H}, \mathrm{CH}_{3} \mathrm{H}$-atoms of $\mathrm{CH}_{3} \mathrm{CH}_{2} \mathrm{~N}^{+}$-quinolinium); $2 \cdot 4\left(q, 2 \mathrm{H}, \mathrm{CH}_{2} \mathrm{H}\right.$-atoms of $\mathrm{CH}_{3} \mathrm{CH}_{2} \mathrm{~N}^{+}-$ quinolinium); $6 \cdot 7-9 \cdot 3(\mathrm{~m}, 17 \mathrm{H}$, aromatic + heterocyclic $+=\mathrm{CH}-\mathrm{H}$-atoms $)$.

\section{2e 2-Ethyl-1,4-diphenyl-1H-pyrazolo[4,5-d][1,3]oxazole-5-one-3[4(1)]-monomethine}

cyanine dyes $(\boldsymbol{6} \boldsymbol{a}-\boldsymbol{c})$ : A mixture of equimolar amounts of 4 (4.47 gm, 0.01 mole) and iodoethane quaternary salt of pyridine $(2.35 \mathrm{gm}, 0.01 \mathrm{~mole})$, quinoline $(2.85 \mathrm{gm}, 0.01$ mole), and isoquinoline $(2.85 \mathrm{gm}, 0.01 \mathrm{~mole})$ in ethanol $(50 \mathrm{ml})$ was refluxed for $7-9 \mathrm{~h}$ in presence of piperidine (5-7 drops). The mixture was filtered while hot, concentrated, cooled and acidified with acetic acid. The precipitated product which appeared on dilution with water was filtered, washed with water several times, dried and recrystallized from ethanol. The data are shown in table 2.

IR spectrum $(\mathrm{KBr})\left(\mathrm{cm}^{-1}\right)$ for $\mathbf{6 b}$ : 694, 753 (benzene mono-substituted); 829, 896 (benzene disubstituted); 1078, $1199(\mathrm{C}-\mathrm{O}-\mathrm{C}$ cyclic); $1308(\mathrm{C}-\mathrm{N}) ; 1539(\mathrm{C}=\mathrm{N}), 1596$ $(\mathrm{C}=\mathrm{C}) ; 1702(\mathrm{C}=\mathrm{O}) ; 2925$ (quaternary salt).

${ }^{1} \mathrm{H}$ NMR spectrum $\left(\mathrm{CDCl}_{3}\right)$ (d) for $\mathbf{6}$ : $1.2\left(t, 3 \mathrm{H}, \mathrm{CH}_{3} \mathrm{H}\right.$-atoms of $\mathrm{CH}_{3} \mathrm{CH}_{2} \mathrm{~N}$ pyrazole); $2 \cdot 1\left(q, 2 \mathrm{H}, \mathrm{CH}_{2}\right.$ H-atoms of $\mathrm{CH}_{3} \mathrm{CH}_{2} \mathrm{~N}$-pyrazole); $1.4\left(t, 3 \mathrm{H}, \mathrm{CH}_{3} \mathrm{H}\right.$-atoms of $\mathrm{CH}_{3} \mathrm{CH}_{2} \mathrm{~N}^{+}$-quinolinium); 2.3 (q, 2H, $\mathrm{CH}_{2} \mathrm{H}$-atoms of $\mathrm{CH}_{3} \mathrm{CH}_{2} \mathrm{~N}^{+}$-quinolinium); 6.6-9.2 ( $m, 17 \mathrm{H}$, aromatic + heterocyclic $+=\mathrm{CH}-\mathrm{H}$-atoms $)$.

3.2f Intermediate compound (7): Equimolar amounts of 4 (4.47 gm, 0.01 mole) and triethyl orthoformate $(1.48 \mathrm{gm}, 0.01$ mole) were dissolved in ethanol $(30 \mathrm{ml})$, and piperidine (5-7 drops) was then added. The reaction mixture was heated under reflux for 5-7 h, filtered while hot, concentrated, cooled, acidified with acetic acid and diluted with water. The precipitated products were filtered and recrystallized from ethanol to give the intermediate compound 7 (see table 3).

IR spectrum $(\mathrm{KBr})\left(\mathrm{cm}^{-1}\right)$ for 7: 694, 753 (benzene mono-substituted); 1072, 1175 (C-O-C cyclic); 1232 (acetal); $1309(\mathrm{C}-\mathrm{N}) ; 1597(\mathrm{C}=\mathrm{N}), 1648(\mathrm{C}=\mathrm{C}) ; 1705(\mathrm{C}=\mathrm{O})$; 2925 (quaternary salt). 
${ }^{1} \mathrm{HNMR}$ spectrum $\left(\mathrm{CDCl}_{3}\right)$ ( $\delta$ ) for 7: 1.45 (t, 3H, $\mathrm{CH}_{3} \mathrm{H}$-atoms of $\mathrm{CH}_{3} \mathrm{CH}_{2} \mathrm{~N}^{+}$pyrazolum); 2.35 ( $q, 2 \mathrm{H}, \mathrm{CH}_{2} \mathrm{H}$-atoms of $\mathrm{CH}_{3} \mathrm{CH}_{2} \mathrm{~N}^{+}$-pyrazolum); $0.95\left(t, 6 \mathrm{H}, 2 \mathrm{CH}_{3} \mathrm{H}\right.$ atoms of $\left.2 \mathrm{OC}_{2} \mathrm{H}_{5}\right) ; 1.65\left(q, 4 \mathrm{H}, 2 \mathrm{CH}_{2} \mathrm{H}\right.$-atoms of $\left.2 \mathrm{OC}_{2} \mathrm{H}_{5}\right) ; 3.40\left(d, 2 \mathrm{H}, \mathrm{CH}_{2} \mathrm{H}\right.$-atoms of $\mathrm{CH}_{2} \mathrm{CH}(\mathrm{OEt})_{2} ; 1.6\left(t, 1 \mathrm{H}, \mathrm{CH} \mathrm{H}\right.$-atom of $\left.\mathrm{CH}_{2} \mathrm{CH}(\mathrm{OEt})_{2}\right) ; 6.7-8.5(m, 10 \mathrm{H}$, aromatic H-atoms).

3.2g 2-Ethyl-1,4-diphenyl-1H-pyrazolo[4, 5-d][1, 3]oxazole-5[2(4)]-mono-3[2(4)]-trimethine mixed cyanine dyes $(\mathbf{8 a}-\mathrm{c})$ : Molar ratios $(1: 2)$ of 7 (5.49 gm, 0.01 mole) and iodoethane quaternary salt of 2(4)-methylpyridine (4.98 gm, 0.02 mole) or quinoline $(5.98 \mathrm{gm}, 0.02 \mathrm{~mole})$ were refluxed for $3-5 \mathrm{~h}$ in ethanol $(30 \mathrm{ml})$ containing a few drops of piperidine. The precipitated compounds after cooling and acidified with acetic acid were filtered and recrystallized from aqueous ethanol (see table 3 ).

IR spectrum $(\mathrm{KBr})\left(\mathrm{cm}^{-1}\right)$ for $8 \mathbf{b}: 694,753$ (benzene mono-substituted); 830, 873 (benzene disubstituted); 1080, 1183 (C-O-C cyclic); 1308 (C-N); $1543(\mathrm{C}=\mathrm{N}), 1597$ $(\mathrm{C}=\mathrm{C}) ; 2924$ (quaternary salt).

${ }^{1} \mathrm{HNMR}$ spectrum $\left(\mathrm{CDCl}_{3}\right)$ (ठ) for $8 \mathrm{~b}: 1.3\left(t, 3 \mathrm{H}, \mathrm{CH}_{3} \mathrm{H}\right.$-atoms of $\mathrm{CH}_{3} \mathrm{CH}_{2} \mathrm{~N}$ pyrazole); $2 \cdot 2$ ( $q, 2 \mathrm{H}, \mathrm{CH}_{2} \mathrm{H}$-atoms of $\mathrm{CH}_{3} \mathrm{CH}_{2} \mathrm{~N}$-pyrazole); $1.5\left(t, 3 \mathrm{H}, \mathrm{CH}_{3} \mathrm{H}\right.$-atoms of $\mathrm{CH}_{3} \mathrm{CH}_{2} \mathrm{~N}^{+}$-quinolinium at position 5); $2.4\left(q, 2 \mathrm{H}, \mathrm{CH}_{2} \mathrm{H}\right.$-atoms of $\mathrm{CH}_{3} \mathrm{CH}_{2} \mathrm{~N}^{+}$quinolinium at position 5); $1.6\left(t, 3 \mathrm{H}, \mathrm{CH}_{3} \mathrm{H}\right.$-atoms of $\mathrm{CH}_{3} \mathrm{CH}_{2} \mathrm{~N}^{+}$-quinolinium at position 3); $2.5\left(q, 2 \mathrm{H}, \mathrm{CH}_{2} \mathrm{H}\right.$-atoms of $\mathrm{CH}_{3} \mathrm{CH}_{2} \mathrm{~N}^{+}$-quinolinium at position 3); 6.7-9.8 ( $m, 26 \mathrm{H}$, aromatic + heterocyclic $+=\mathrm{CH}-\mathrm{H}$-atoms $)$.

$3.2 \mathrm{~h}$ 5-Acylmethylideno derivatives as intermediate compounds (9a-e): Equimolar amounts of 3 (2.91 gm, 0.01 mole) and the carbonyl compound (acetaldehyde) ( $0.44 \mathrm{gm}$, 0.01 mole $)$, acetone ( $0.58 \mathrm{gm}, 0.01 \mathrm{~mole})$, acetophenone (1.2 gm, 0.01 mole), 4-methoxy acetophenone (1.5 gm, 0.01 mole), 4-nitroacetophenone (1.65 gm, 0.01 mole) were heated under reflux in ethanol $(30 \mathrm{ml})$ with piperidine $(5-7$ drops $)$ catalysis for 5-7 $\mathrm{h}$. The reaction mixture was filtered while hot, concentrated and the isolated resinous material was triturated with ether followed by water where the precipitated products were filtered and recrystallized from aqueous ethanol (table 4).

IR spectrum $(\mathrm{KBr})\left(\mathrm{cm}^{-1}\right)$ for 9a: 693, 756 (benzene mono-substituted); 1012, 1115 (C-O-C cyclic); $1310(\mathrm{C}-\mathrm{N}) ; 1556(\mathrm{C}=\mathrm{N}) ; 1597(\mathrm{C}=\mathrm{C}) ; 1707(\mathrm{CHO})$.

${ }^{1} \mathrm{HNMR}$ spectrum $\left(\mathrm{CDCl}_{3}\right)(\delta)$ for 9a: 0.85 ( $s, 3 \mathrm{H}, \mathrm{CH}_{3} \mathrm{H}$-atoms); 6.7-8.0 (m, 11H, aromatic $+=\mathrm{CH}-\mathrm{H}$-atoms $) ; 9.75(d, 1 \mathrm{H}, \mathrm{CHO} \mathrm{H}$-atom $)$.

3.2i 3-Methyl-1,4-diphenyl-1H-pyrazolo[4,5d][1,3]oxazole-5(2)-tri-and meso substituted tri-methine cyanine dyes (10a-e): Equimolar amounts of 9a-e (3.17 gm, 0.01 mole; $3.31 \mathrm{gm}, \quad 0.01 \mathrm{~mole} ; 3.93 \mathrm{gm}, 0.01 \mathrm{~mole} ; 4.23 \mathrm{gm}, 0.01 \mathrm{~mole} ; 4.38 \mathrm{gm}, 0.01 \mathrm{~mole}$ ) and iodoethane quaternary salt of 2-methylquinoline $(2.99 \mathrm{gm}, 0.01 \mathrm{~mole})$ were dissolved in ethanol $(30 \mathrm{ml})$, to which piperidine $(5-7)$ drops was added. The reaction mixture was refluxed for 3-5 h. until it attained a permanent colour, filtered while hot, concentrated, cooled and acidified with acetic acid. The precipitated products were filtered and recrystallized from ethanol, characterization data are shown in table 4.

IR spectrum $(\mathrm{KBr})\left(\mathrm{cm}^{-1}\right)$ for 10a: 694, 753 (benzene mono-substituted); 834, 873 (benzene disubstituted); 1085, 1123 (C-O-C cyclic); $1310(\mathrm{C}-\mathrm{N}) ; 1496(\mathrm{C}=\mathrm{N}) ; 1597$ (C=C); 2925 (quaternary salt). 
${ }^{1} \mathrm{H}$ NMR spectrum $\left(\mathrm{CDCl}_{3}\right)(\delta)$ for 10a: $0.98\left(s, 3 \mathrm{H}, \mathrm{CH}_{3} \mathrm{H}\right.$-atoms); $1.55\left(t, 3 \mathrm{H}, \mathrm{CH}_{3}\right.$ H-atoms of $\mathrm{CH}_{3} \mathrm{CH}_{2} \mathrm{~N}^{+}$-quinolinium); $2.45\left(q, 2 \mathrm{H}, \mathrm{CH}_{2}\right.$ H-atoms of $\mathrm{CH}_{3} \mathrm{CH}_{2} \mathrm{~N}^{+}-$ quinolinium $) ; 6 \cdot 7-9 \cdot 5(\mathrm{~m}, 19 \mathrm{H}$, aromatic + heterocyclic $+=\mathrm{CH}-\mathrm{H}$-atoms $)$.

$3.2 \mathrm{j} \quad 2-$ Ethyl

iodide-1,4-diphenyl-1H-pyrazolum[4,5d][1,3] oxazole-5-one-3(1)-azadimethine cyanine dyes $(\mathbf{1 1 a - c})$ : A mixture of equimolar ratios $(0.01 \mathrm{~mole})$ of 4 (4.47 gm, 0.01 mole) and the nitroso compounds ( $p$-nitrosophenol (1.23 gm, 0.01 mole), $\alpha$-nitroso- $\beta$-naphthol (1.73 gm, $0.01 \mathrm{~mole}), \beta$-nitroso- $\alpha$ naphthol (1.73 gm, 0.01 mole)) was refluxed in presence of piperidine (5-7 drops) as basic catalyst and ethanol (30 ml) as organic solvent for $9-13 \mathrm{~h}$. The reaction mixture attained a permanent deep brown/violet colour. It was filtered off while hot, cooled and acidified with acetic acid. The precipitated product after dilution with cold water was filtered off, washed with water, and crystallized from ethanol, relevant data are given in table 5.

IR spectrum $(\mathrm{KBr})\left(\mathrm{cm}^{-1}\right)$ for 11c: 695, 753 (benzene mono-substituted); 831, 894 (benzene disubstituted); 1072, $1110(\mathrm{C}-\mathrm{O}-\mathrm{C}$ cyclic); $1310(\mathrm{C}-\mathrm{N}) ; 1596(\mathrm{C}=\mathrm{N}) ; 1648$ $(\mathrm{C}=\mathrm{C}) ; 1704(\mathrm{C}=\mathrm{O}) ; 2924$ (quaternary salt); $3290(\mathrm{OH})$.

${ }^{1} \mathrm{H} N M R$ spectrum $\left(\mathrm{CDCl}_{3}\right)$ (d) for 11c: $1.4\left(t, 3 \mathrm{H}, \mathrm{CH}_{3} \mathrm{H}\right.$-atoms of $\mathrm{CH}_{3} \mathrm{CH}_{2} \mathrm{~N}^{+}-$ pyrazolum); $2 \cdot 3\left(q, 2 \mathrm{H}, \mathrm{CH}_{2} \mathrm{H}\right.$-atoms of $\mathrm{CH}_{3} \mathrm{CH}_{2} \mathrm{~N}^{+}$-pyrazolum); 6.7-9.4 ( $m, 18 \mathrm{H}$, aromatic + naphthyl $+=\mathrm{CH}-+\mathrm{OH} \mathrm{H}$-atoms).

\subsection{Spectral behaviour}

Spectral behaviour of all the synthesized cyanine dyes in $95 \%$ ethanol were recorded using $1 \mathrm{~cm}$ cells. A stock solution $\left(10^{-3} \mathrm{M}\right)$ of the dyes was diluted to appropriate volume in order to obtain the required concentrations.

\section{References}

1. Broker L G S and Keyes G H 1935 J. Am. Chem. Soc. 572488

2. Eastman Kodak Co. 1980 US Patent 4232121

3. Eastman Kodak Co. 1980 US Patent 4226868

4. Terutaro O 1953 Rep. Sci. Res. Inst., Japan 29507

5. Lykov V P, Khovrychev M P and Polin A N 1987 Otkryt. Izobret. 34 93; 1988 Chem. Abstr. $108164429 \mathrm{w}$

6. Abd El-Aal R M, Shindy H A and Koraiem A I M 1997 Heteroatom Chemistry 8259

7. Koraiem A I M and Shindy H A 1998 Chem. Papers 52762

8. Yoshida A, Tanaka A and Tsubai Y 1979 US Patent 4134 769; 1979 Chem. Abstr. 90 $213240 \mathrm{y}$

9. Koraiem A I M, El-Maghraby M A, Khalafalla A K and Shindy H A 1989 Dyes Pigments 11 47

10. Shindy H A 1999 J. Chem. Res. (S) 700; Shindy H A 1999 J. Chem. Res. (M), 3001

11. Koraiem A I M, Shindy H A and Abu El-Hamd R M 1999 Proc. Indian Acad. Sci. (Chem. Sci.) 111709

12. Bellamy L J 1962 The infrared spectra of complex molecules (London: Methuen) p 249

13. Schimann F 1970 Nuclear magnetic resonance of complex molecules (Brauunschweig: Vieweg und Sohn) vol 1, p 41

14. Koraiem A I M 1989 Indian J. Chem. B28 659

15. Osman A M and Khalil Z H 1975 J. Appl. Chem. Biotechnol. 25683 